IZA DP No. 9516

Migrants' Remittances: Channelling Globalization

Remus Gabriel Anghel

Matloob Piracha

Teresa Randazzo

November 2015 


\title{
Migrants' Remittances: Channelling Globalization
}

\author{
Remus Gabriel Anghel \\ Romanian Institute for Research on National Minorities
}

Matloob Piracha

University of Kent

and IZA

Teresa Randazzo

University of Kent

\section{Discussion Paper No. 9516 \\ November 2015}

\author{
IZA \\ P.O. Box 7240 \\ 53072 Bonn \\ Germany \\ Phone: +49-228-3894-0 \\ Fax: +49-228-3894-180 \\ E-mail: iza@iza.org
}

\begin{abstract}
Any opinions expressed here are those of the author(s) and not those of IZA. Research published in this series may include views on policy, but the institute itself takes no institutional policy positions. The IZA research network is committed to the IZA Guiding Principles of Research Integrity.

The Institute for the Study of Labor (IZA) in Bonn is a local and virtual international research center and a place of communication between science, politics and business. IZA is an independent nonprofit organization supported by Deutsche Post Foundation. The center is associated with the University of Bonn and offers a stimulating research environment through its international network, workshops and conferences, data service, project support, research visits and doctoral program. IZA engages in (i) original and internationally competitive research in all fields of labor economics, (ii) development of policy concepts, and (iii) dissemination of research results and concepts to the interested public.
\end{abstract}

IZA Discussion Papers often represent preliminary work and are circulated to encourage discussion. Citation of such a paper should account for its provisional character. A revised version may be available directly from the author. 
IZA Discussion Paper No. 9516

November 2015

\section{ABSTRACT}

\section{Migrants' Remittances: Channelling Globalization*}

In the past twenty years the ever-growing levels of migrants' remittances made state agencies, international organizations, scholars and practitioners to increasingly consider remittances as one of the main engines to promote globalization and growth in the developing world. By transferring home large amounts of money, information, ideas and practices, migrants and migrant organizations are often seen as able to produce significant changes in countries and localities of origin. Focusing on cases from former socialist countries and around the world, this paper discusses the main debates surrounding the effects and uses of migrant remittances. Furthermore, using different case studies from Europe and Asia, the paper addresses the notion of social remittances, namely the transfers of ideas, practices and norms between societies of origin and destination. It highlights the ideas and practices migrants transfer home, the types of social norms it generates, and the extent to which migration produces transformations in countries of origin.

JEL Classification: F22, F24

Keywords: remittances, social remittances, former socialist countries

Corresponding author:

Matloob Piracha

School of Economics

Keynes College

University of Kent

Canterbury, Kent CT2 7NP

United Kingdom

E-mail: M.E.Piracha@kent.ac.uk

\footnotetext{
* A revised version is published in: Leila Simona Talani and Simon McMahon (eds.), Handbook of the International Political Economy of Migration, Edward Elgar 2015, Cheltenham, UK, and Northampton, USA, Chapter 11, 234-258.

Remus Anghel is grateful for the financial support from the project CNCS PN-II-ID-PCE-2011-3-0602, "Recasting Migrants' Voices. Local Perspective on Migration, Development and Social Change in Romania."
} 


\section{Introduction}

The growing pace of globalization around the world, accompanied by major transformations in countries of origin and significant economic changes in the industrialised countries have resulted in ever-growing migratory dynamics around the world. Migration is a global phenomenon which touches every region in the world either as sending, transit or receiving countries. Remittances represent one of the most consistent outcomes of migration. Through remittances, migrants transfer funds, information, ideas and practices. Remittances link societies of origin and destination by multiple processes of mobility and exchange.

Migrant remittances are transfers that are conducted by migrants between countries of origin and destination. Remittances consist of monetary and non-monetary transfers (named financial remittances) as well as ideas, values, and modes of action (named social remittances). Unlike capital flows, which are made of money invested by international institutions, companies and individuals seeking higher profits and interest rates, financial remittances are transferred by migrants themselves to households, communities and countries of origin. Migrant remittances represent migrants' continuous involvements in their places and communities of origin. Different from capital flows and FDI, which are usually sent formally, financial remittances may be transferred by both using formal and informal channels. In some cases, informal transfers channel a large part of financial remittances.

The research on remittances is a hugely debated topic, with contributions coming from around the world, and this paper mainly focuses on findings from former socialist countries that experienced international migration mostly in the past twenty years. The paper first assesses the importance of remittances, representing one of the main avenues of capital flows towards poorer countries. It follows with the analysis of the use and impact of remittances: use by households and effects on poverty and inequality, and on individual occupational choices. At the macro level also, debates evolve around the positive or negative role of remittances on growth and country competitiveness. The second part of the paper analyses the types and the effects of social remittances. It discusses the new ideas that migrants transfer to communities of origin, such as notions of wealth and consumption, the practices associated with business and management that they import back home, and the social norms associated with gender relations.

\section{The relevance of remittance flows}

Remittances play a central role in the debate on migration and development in relatively poor economies. The labour migration process can be explained by a simple push-and-pull model. On the one hand, conflict, natural disaster, poverty, inequality in the distribution of resources, 
unemployment in the origin region represent "push factors" for migration while on the other hand, higher wages, more opportunities, family reunification in the destination countries are "pull factors" in the migration process (IOM, 2013). Overall, labour migration dominates the human mobility: people move in search of better economic opportunities and they generate large flows of remittances to their countries of origin.

Remittances are not a new outcome of migration, though the lack of reliable data has made the evaluation of their impact on recipient countries quite challenging. The difficulties in measuring remittances depend on the private nature of these transfers, which quite often reach the recipient households through unofficial channels. In fact, it is extremely difficult to estimate the flows of money sent with informal operators or hand carried by individuals, making the unofficial remittances a considerably large chunk of the total flows - the volume of these flows could be at least 50 per cent more than what the official estimates suggest (World Bank, 2006). Recently, many household surveys include sections on migration and remittances and the availability of more information has generated a number of studies which cover nearly all regions in the world. Moreover, the World Bank has recently launched several projects for understanding the reasons and impacts of migration and remittances in developing countries.

Remittances are characterized by their volume, growth and stability (Ratha, 2003). The flow of remittances to developing countries is quite consistent and it reflects the fact that the large flow of labour migration is from low-and-middle income countries ("South") to high-income countries ("North"). According to the World Bank (2010) the South-North labour flow represents 45 per cent of the total followed by South-South migration (35 per cent), North-North (17 per cent) and NorthSouth (3 per cent) (IOM, 2013).

The official flow of money transfers from migrants to their countries of origin almost tripled between 1998 and 2008, consisting of \$338 billion to developing countries (Ratha et al., 2009). The World Bank reports that official remittances to developing countries are expected to reach $\$ 414$ billion in 2013, growing by 6.3 per cent over 2012 and increased 12.1 per cent between 2010 and 2011 (World Bank, 2013b). As shown in Figure 1, remittances are expected to grow more in the coming years. In many countries they exceed official development assistance and are also larger than private debt and portfolio equity flows. In addition, remittances represent an important source of foreign currency earnings. 
Figure 1: Remittance flows

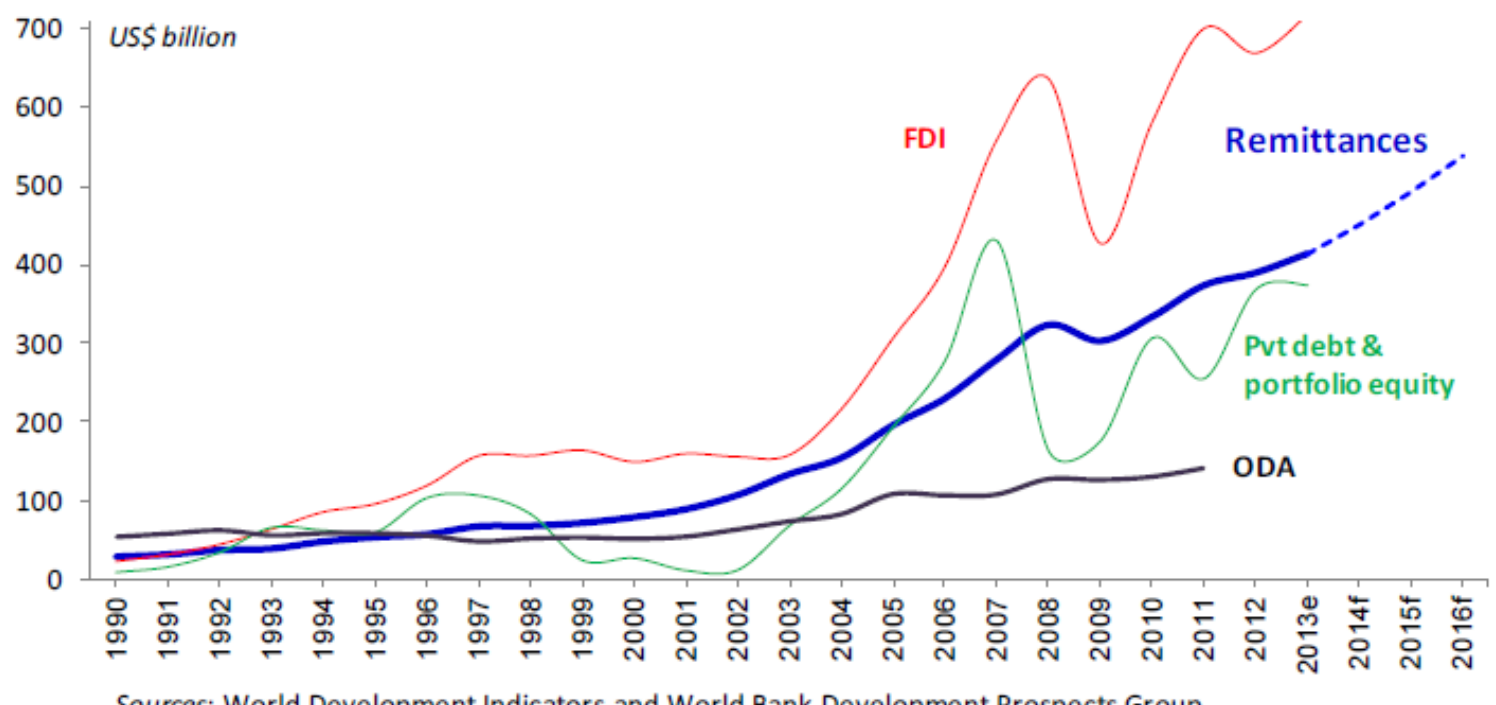

Sources: World Development Indicators and World Bank Development Prospects Group

Unlike capital flows, which rise during economic booms and fall in recessions, remittances are generally considered a relatively stable source of foreign exchange, and some evidence suggests that they are actually countercyclical. During economic downturns in the home country workers are inclined to migrate abroad, as push factors become even stronger, and therefore the flow of remittances is likely to increase. Also, those already abroad tend to transfer a large amount of remittances to their relatives in the home country, possibly due to altruistic motives for the wellbeing of those left-behind.

The recent economic crisis of 2008 , which affected a number of major migrant destination countries, was expected to affect employment opportunities and therefore migrants' income compromising the willingness and ability of migrants to stay in their host countries and continue to send remittances. To a certain extent, the volume of remittances decreased during 2009 but it was only by 5.2 per cent with respect to the pre-crisis period and overall remittance flows proved to be significantly more resilient than private capital flows, which declined precipitously (World Bank, 2012). Nevertheless, remittances returned to growth in the following years as shown in Figure 1.

Given the peculiar characteristics discussed above, the large flows of migrant earnings into migrant sending areas have inspired researchers to carry out surveys to quantify remittances, their use and their impact on the local economies. India ( $\$ 70$ billion), China ( $\$ 60$ billion), the Philippines (\$25 billion) and Mexico (\$22 billion) are the largest recipient of migrant remittances (World Bank, 2013a,b). For smaller low-income countries remittances represent a higher share of their GDP (see Fig. 2). The volume of remittances varies consistently within and between regions. Historical, political, social and economic aspects play a key role in explaining and understanding migrants' transfers. Moreover, remittances trends are also influenced by the circumstances in the destination 
countries. For instance, the collapse of the Soviet Union in 1990 and subsequent opening up of the border of a number of affected countries resulted in a significant movement of people from Eastern and Central Europe to the industrialised countries, particularly EU15, the US and also to Russia (primarily from Central Asian countries but also from Moldova and Ukraine). As a result, there has been a significant increase in remittance flows to this region, and is estimated to have reached \$42.6 billion in 2013. And, it is expected that the flow of remittances will be larger thanks to the economic recovery in the EU countries and the continued strong economic growth in Russia.

Among the Eastern Europe countries, Ukraine is the largest recipient in the region. According to the World Bank (2013b), the inflow of remittances was $\$ 9.3$ billion in 2012. Figure 2 shows that Tajikistan and Romania follow with $\$ 4.1$ and $\$ 3.6$ billion respectively, falling from $\$ 9.3$ billion in 2007 (Horváth and Anghel 2009). According to some experts, without remittances the current account deficits in Romania would have been over 50 per cent higher (Goschin et al., 2011).

Figure 2: Top recipient remittance former socialist countries

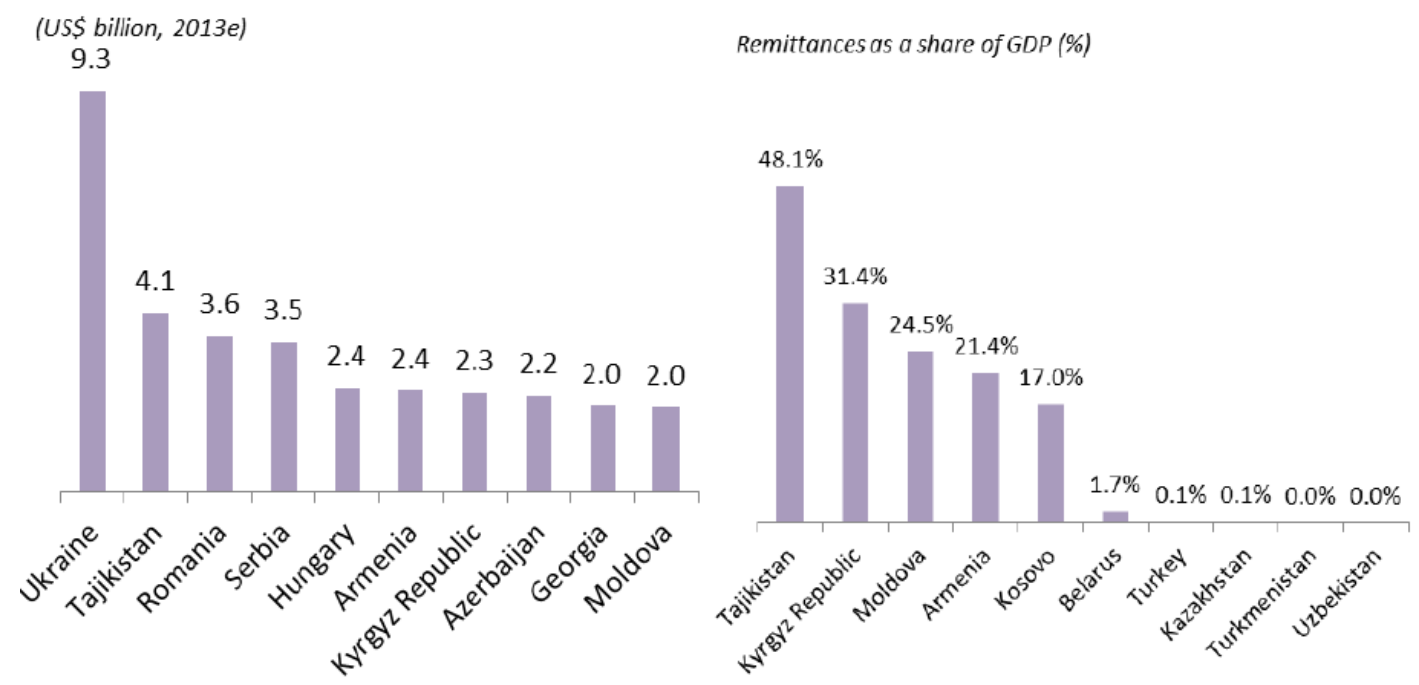

Source: Central Banks of the respective countries. Graph elaborated by The World Bank (2013)

Former socialist countries are at the top of the list of those with remittances representing a high share of a country's GDP. Migration and remittances are significant in the region. For example, remittances in Tajikistan represent almost 50 per cent of the country GDP, followed Kyrgyz Republic, Moldova, Armenia and Kosovo for which remittances represent between 20 and 30 per cent of their countries GDP (World Bank, 2012 and 2013). In fact, following the breakup of the Soviet Union in 1991, these countries experienced a consistent flow of emigration which characterized the transition process and has continued to be relevant more recently. In the early 
period of transition migration was driven mainly by ethnic and conflict reasons. While later, as the situation stabilized, economic reasons became the main push factor.

These small developing countries were not able to face the challenges that a transition from a centralized to a market economy brought. They faced a staggering level of unemployment and consequent poverty and instability which had a significant impact on their development process and represented push factors for emigration. For example, Tajikistan and Moldova, two of the poorest countries in the world, started their independence with long civil wars, respectively. Despite economic reforms in the last decade, with substantial welfare improvements, poverty remains a threat for the majority of those populations. Migrant's remittances represent an important source of income for many households who see in this flow of money the way to provide for the basic need of their members. For many Eastern European countries, remittances are the second most important source of external financing after foreign direct investment. For instance, remittances were higher than exports, net foreign direct investment and official development aid received by Albania, and covered almost one third of the trade deficit (Gedeshi and Jorgoni 2012; Lucas, 2005). As a percentage of the GDP, the World Bank (2011) ranks Albania among the 20 leading remittancereceiving countries and among the first in Eastern Europe and the Former Soviet Union.

\section{Use and Economic Implications of Remittances}

Given the presence of inequality in the distribution of resources, job opportunities and level of income, migration and remittances can work as equilibrating mechanisms between sending and receiving countries. On the one hand, migration and remittances can represent a response to the failure of national economic policy to address individual and public needs in terms of economic opportunities; while on the other hand, remittances can be a powerful tool for economic policy in the development process. The economic, social and cultural implications of remittances, both for sending and receiving countries, are enormous. For example, changes to the population and to family structures, as well as reorganization of the labour market are some visible signs of the movement of individuals which sending and receiving countries experience in different directions. In countries of origin, levels of poverty, inequality, and household expenditure decisions are some of the channels through which the flow of migrant's transfers discloses its effects on growth and development. The next section will look at some of these implications in more detail.

\subsection{The impact of remittances on poverty and inequality}

First of all, remittances directly affect poverty by increasing the income of the recipient household (World Bank, 2006). A large number of case studies present evidence that remittances reduce 
poverty, although this reduction is small. Adams and Page (2005) have conducted the broadest evaluation of the impact of international migration and remittances on developing countries, covering 71 low- and middle-income countries. They show that a 10 per cent increase in per capita international remittances leads to a reduction of people living in poverty by 3.5 per cent. Also, Acosta et al. (2008), examining the impact of remittances on poverty for 10 Latin American countries, conclude for a positive impact, although modest, on poverty reduction. At the country level, Adams and Cuecuecha (2010b) for Indonesia, Lokshin et al. (2010) for Nepal, Adams et al. (2008b) for Ghana and Taylor et al. (2005) for Mexico show evidences supporting the positive effect of remittances on poverty reduction. However, the size of poverty reduction depends on the type of remittances being received. In general, international remittances have a greater impact on poverty reduction than internal remittances (Adams et al., 2008b).

While there is a clear indication that remittances reduce poverty, the evidence on the effect of remittances on inequality is mixed. A large number of studies show that remittances have a negative impact on income inequality, as measured by the Gini coefficient (Barham and Bousher, 1998; Rodriguez, 1998; Adams et al., 2008b, Adams and Cuecuecha, 2010a), and this effect is more pronounced when remittances come from international as opposed to internal migrants. The reason for this negative outcome of remittances is simple: international migration is costly and therefore those receiving international remittances are not the poorest but generally tend to come from middle or upper-income groups, and further increase in their income from remittances exacerbates inequality in the country. However, De and Ratha (2005) found that the Gini coefficient drops for the effect of remittances while McKenzie and Rapoport (2007) found that even though the initial effect of migration is to increase income inequality, as the level of migration increases income inequality decreases. Given the mixed findings the relation between remittances and income inequality is still a topic of debate.

Remittances do not produce outcomes only on the level of poverty and income inequality. The remittances process also affects the family members left-behind in both positive and negative ways. First of all, the consequence of migration is the loss of a member contributing to the household income. This negative "shock" on the household labour supply may force the remaining members to fill the production gap, with the consequence of giving less care and assistance to the younger members and/or to the elderly in the family. Moreover, a parent migrating could result in the children left-behind facing emotional stress as they receive less supervision and care and they could be forced to contribute to the household work with negative consequences on their learning or education decision. On the other side however, in case of the head of the household migrating, the spouse may take a more active role in the household decisions. In some developing countries, where 
the role of women is marginal in households and communities of origin, it may be an important step for emancipation.

\subsection{The use of remittances}

Migrant's remittances compensate for the absence of a family member and the first evaluation between cost and benefit of migration depends on how migrant's income is used by the recipient household. In fact, given that consumption responds to income changes, households receiving remittances can orientate differently their expenditure decision. Generally, preferences for consumption are limited by income constraints and this is an important issue in low-income countries where quite often it is difficult to maintain consumption above the subsistence level. The contribution of migrant's income on individual and household expenditure decisions can have important implications on growth and development when consumption is oriented to productive goods and activities.

The debate on the role of remittances on a household's expenditure is not limited to the fact that remittances are an additional source of earnings, which is added to the household income, but also that remittances may include additional information which give them an additional value. How remittances are used, and therefore how consumption is oriented, depend on how remittances are perceived by the recipient households. Three views exist on how households interpret and use remittances. The most recent view concludes for a productive use of remittances: they are transitory income and are spent more on investment goods - human and physical capital investment - instead of consumption goods. Empirical studies showing that remittances contribute to children's education (Edward and Ureta, 2003; Kifle, 2007; Yang, 2008; Adams and Cuecuecha, 2010a; Mansour et al., 2011), housing (Adams and Cuecuecha, 2010a) health (Taylor and Mora, 2006) and/or investments (Woodruff and Zenteno, 2004; Taylor and Mora, 2006) affirm that remittances have a positive impact on economic development by increasing the level of investment in human and physical capital. The opposite view argues that remittances cause behavioural changes and are spent on consumption rather than investment goods (Chami et al., 2005; Adams and Cuecuecha, 2010b; Clément, 2011). This is quite a pessimistic view on the use of remittances, which may also lead to household dependency on migrant's income with negative effect on the economic development. The last view on remittances does not support any expenditure behaviour change caused by migrant's transfers: remittances are fungible and they are treated just as any other source of income; there is no difference in behaviour between those who receive and those who do not receive remittances (Zarate-Hoyos, 2004; Castaldo and Reilly, 2007; Adams et al., 2008a; Ang et al., 2009; Randazzo and Piracha, 2014). 
Adams and Cuecuecha (2008a) suggest that the way that remittances are perceived by recipient households also depends on the socio-economic context in which they are received. Middle-income households may better understand the value of remittances and use this transitory income productively. Very poor households may value income from remittances just as a wage income and they use it to satisfy their basic needs, which is why some empirical evidence cannot support a productive use of these transfers (see for instance Castaldo and Reilly, 2007; Randazzo and Piracha, 2014). However, it is possible that in the long-run, after the household is able to cover its basic needs, the role and perception of remittances change. In the presence of capital market imperfection, remittances can also be crucial in overcoming financial difficulties for selfemployment activities. Availability of capital is an important ingredient for starting a business. Entrepreneurship is an important spill-over for economic growth, innovation and competiveness and it should be encouraged in developing countries. However, realizing a new project or activity can be challenging in the presence of credit market constraints. Paulson and Townsend (2004) argue that the lack of capital is the reason why in Thailand households do not start a business or are not able to expand their existing ones. Remittances can compensate for this lack of funds. They can be an important source of development for many poor sending countries through its effects on entrepreneurship and reorganization of the local labour market. For example, under the assumption of capital market imperfections, Mesnard (2004) finds a positive relationship between temporary migration and the choice to become an entrepreneur after return in Tunisia. Migrants accumulate savings during the period abroad and use them to finance self-employed activities after return. The positive impact of accumulated saving overseas on the decision to become a self-employed is also supported by other studies (Ilahi, 2002; Piracha and Vadean, 2010; Demurger and Xu, 2011).

Less attention has being given to the impact of migration on remittances on the occupational choice of non-migrants. A considerable number of studies look at how the labour supply of those left-behind responds to migration in terms of participation and number of hours worked (Dustmann and Kirchkamp, 2002; Founkhouser, 2006; Amuendo-Dorantes and Pozo, 2006; Kim, 2007) but with respect to the types of activity (wage earner or self-employed) more evidences are needed. An exception is Acosta (2007) who conducted a comprehensive investigation on the effect of remittances on labour participation, number of hours worked and occupational choice for those-left behind. Acosta found that remittances increase the probability of self-employment among men while recipient females are more likely to work in own microenterprise setup. And, across gender the effect is much stronger in rural areas. This evidence suggests a productive use of remittances: migrant's income can help boost business in the presence of lack of capital. This hypothesis is 
supported by Woodruff and Zenteno (2007) who find that migrant's income is positively associated with microenterprise investment in Mexico.

\subsection{Some concerns about remittances}

As mentioned above, migration and remittances are not without costs. One cause for concern is how remittances affect the organization of the migrant's households in term of duties and roles. For example, evidence shows that those receiving remittances decrease their participation in the labour market (Acosta, 2006; Funkhouser, 2006; Kim, 2007; Justino and Shemyakina, 2010). Remittances can substitute the income produced in the home country, making those left-behind less enthusiastic to join the labour market. In fact, an individual's reservation wage increases when they receive remittances, and this generally results in a reduction in labour force participation (see Kim, 2007 and Funkhouser, 2006). Amuedo-Dorantes and Pozo (2006), however, showed that remittances do not change the overall labour supply of men but their effect influences the employment composition. Using Mexican data, they showed that the external inflow of income causes a reduction of hours worked in the formal sector and an increase in the informal one both in rural and urban areas. This suggests that individuals receiving remittances prefer moving to more flexible and informal jobs. For women, the overall labour supply declines for effect of remittances but only in rural areas.

Migration and remittances are indeed closely related processes. The phenomenon of brain drain, by which there is movement of skilled people from developing countries with a low level of human capital, is among the downsides of migration. Highly educated individuals generate positive externalities for the society and these are lost when they migrate. Some of the positive externalities associated with skilled people are: productive ideas; positive effects on the productivity of other workers; the importance and supply of critical public services such as education and health; the fiscal externalities associated with the fact that the value of the taxes paid is larger than the value of the public services consumed by the skilled individuals. Moreover, highly educated citizens contribute to the quality of the debate on important social issues and they impact policy and institutions (World Bank, 2006). Therefore, brain drain may represent a consistent loss in term of knowledge, experience and productive inputs which may not be adequately compensated by the migrant's flow of remittances. However, this negative view has been opposed by a more optimist perspective celebrating brain circulation instead of brain drain and the potential of highly skilled returnees to produce institutional transformations in countries of origin (Faist, 2010). 


\subsection{Macroeconomic effect of remittances}

Remittances do not affect exclusively the choices of the recipients. Households without migrants, and whole countries, may benefit from positive spillover effects. If remittances drive economic activities contributing to stimulate the local economy, then also those who do not receive remittances are involved in this process (Yang, 2004). In addition, the consistent flow of remittances and the large share they represent in relation to the GDP of many countries suggest that the macroeconomic impact of remittances has relevant implications for growth and development. It is not easy to disentangle the link between remittances and economic growth as there are many interwoven variables and factors.

There is contrasting evidence, some supporting the positive impact of remittances on economic growth and other studies supporting just the opposite. On the one hand, Chami et al. (2005) support a negative view of the effect of remittances on growth (per capita GDP growth). Using 113 countries over the period 1970-1998, they identify remittances as a compensation for countries for poor economic conditions which is not functional for stimulating the economy. Spatafora (2005) in a similar study, using 101 countries for the period 1970-2003, also does not find any link between remittances and growth. Moreover, he does not find any effect of remittances on economic investment and education. Positive findings of remittances on economic growth are supported by Giuliano and Ruiz-Arranz (2009) who find that migrants' transfers do promote GDP growth. Their empirical evidence supports the hypothesis that remittances act as a substitute for inefficient or non-existent credit markets and are instrumental in the growth and development process of the recipient country. Similarly, Catrinescu et al. (2009), using the same data as Chami et al. (2005) but unlike them, controlling for economic and political institutions, find a positive impact of remittances on growth. They argue that negative findings by others, and especially Chami et al., are possibly a result of the omitted variable bias.

Some other studies (Amuedo-Dorantes and Pozo, 2004; Lopez et al., 2007) find that remittances negatively affect the competitiveness of the receiving countries. They cause the appreciation of the real exchange rate between 18 and 24 for per cent for 1 per cent increase of remittances in the GDP ratio. The empirical evidence of the adverse effect of remittances on the real exchange rate are based on Latin American data; however it is possible that the outcome is different in other areas of the world. Rajan and Subramanian (2005) do not find evidence that that remittance flows slow down growth affecting external competitiveness. The use of remittances has been explored for arguably two of the highest migration countries in Eastern Europe and Central Asia: Albania and Tajikistan. In the case of Albania, Castaldo and Reilly (2007) conclude for an insignificant impact of remittances on household expenditure. They control for four categories of 
goods: food, non-food, durables and utilities. Domestic remittances have no effect on any of these expenditure categories while international transfers impact positively the share of expenditure devoted to durables and utilities and negatively the expenditure on food. However, even international remittances lose their impact when the focus is the marginal spending behaviour. A more pessimistic view on the use of remittances is supported by Clément (2011) in the context of Tajikistan. He shows that international transfers increase the household consumption level while decreasing expenditure on investments. Then even if domestic remittances have positive impact on spending on health, he interprets this outcome as a short term priority.

Particular attention on these countries captures the relationship between education expenditure and volume of remittances sent to developing countries. Cattaneo (2011) provides evidence from Albania which does not support any link of investment in education and remittances. While household income has a positive impact on education spending, international transfers do not influence it. In the case of children's schooling in Tajikistan, Kroeger (2010) tries to separate the family out-migration from the remittance effect. In fact, on the one hand, remittances shift household liquidity constraints from which children can benefit, while on the other hand, the migration of a household member can counter this positive effect. His analysis considers school age children (8-18 years) and finds that remittances and presence of migrants in the family have a positive effect in the girls' school enrolment: parents receiving remittances invest more in their daughters' education then those without remittances. Instead, for the sample of males, the school enrolment increases only for the older school age boys (14-18 years). The positive effect of remittances on education decreases significantly when the focus shifts only to households with migrants.

The impact of remittances in Tajikistan has also been explored by Justino and Shemyakina (2010) who explore how labour supply responds to international transfers. They find that adults aged 16 to 65 receiving international transfers are less likely to participate in the labour market and those who do participate tend to work fewer hours than those who don't receive remittances. Finally, León-Ledesma and Piracha (2004) in a macroeconomic study, involving 11 Eastern European countries for the period 1990-1999, support the view that remittances lead to positive outcomes on development and growth. On the one hand, return migrants have a positive impact on the productivity of the source country and on the other hand, remittances contribute to stimulate investments. 


\section{Social remittances and their impact on communities of origin}

The migration literature stresses that migrants do remit only financial resources to their home communities, but also ideas, values, norms, and social practices (Levitt, 1998). This claim stands on the premise that migration is not just an economic, but also a social and cultural process, in which migrant remittances represent more than monetary transactions and have deep and longlasting consequences (Rahman, 2012). These social remittances are transmitted by the use of social capital, through several distinct ways, for instance when migrants travel back home, when migrants' relatives and friends visit them, or through different uses of communication channels, such as the media, internet, telephone, or mail (Levitt and Lamba-Nieves, 2010). As Levitt argues (1998), social remittances have the capacity to diffuse on larger geographical regions and encompass more domains of social life. They may go first to migrant families, but they scale-up to the levels of communities, regions, and even nations. In certain conditions, social remittances scale-out from households to influence economic or religious practices and ideas. Secondly, social remittances can be divided into family/individual remittances and collective remittances. Whereas individual/family remittances are transferred by migrants and migrants' relatives, collective remittances, as "high quality resources" (Goldring, 2003) are transferred at the level of entire collectivities by groups of migrants and migrant associations, such as home town associations (HTA). Different studies unfold how HTA's invest in their origin communities in communal works, public service infrastructure, church activities, recreational and status-related projects (Goldring, 2003; Itzigsohn, 2008). In all these cases migrants are not neutral transmitters of social remittances, but they filter them out in accordance to their interests, values and worldviews (Sussomboon, 2008). Social remittances and migrants' collective projects may also generate tensions and frustration in communities of origin when migrants' visions and projects do not fit to the needs and wishes of those left behind (Lindley, 2009), such as the cases when migrant associations finance communal works that are not deemed important by non-migrants (Itzigson, 2008).

Considered as a forms of "globalization from below", financial and social remittances are often seen as having rather positive outcomes, as they transfer to countries of origin resources, knowledge, ideas and practices considered as "good" "such as human rights, gender equality, community empowerment, voluntary work and charity initiatives" (Conway, et al., 2012: 190). In this view, it is often considered that migration and remittances expand people's ability to control their lives (Vullnetari and King, 2011), that remittances are invested in increasing human capital and in improving health and education (idem). However, as Levitt and Lamba-Nieves argue (2010), they may equally be positive or negative. In some cases social remittances are made of conservative ideas, and the ideas that migrants bring with them are not necessarily more egalitarian, as found in 
the case of Albanians coming from Greece with notions of a patriarchal society in terms of gender relations within households (Vullnetari and King, 2011). In other cases, migrant youth assimilated into the lower strata of the receiving societies can bring back home practices and ideas related to gang and delinquent behaviour (Portes, 1998).

The concept of social remittances is a very seductive one, though in comparison to the research on financial remittances, not much research has been devoted to its study as it is much more difficult to quantify them (Boccagni and Decimo, 2013). Evidence from Ecuador shows that financial and social remittances are linked and both contribute to the development of a country (Mata-Codesal, 2013). Recently, some more efforts were oriented towards understanding the role of social remittances in diffusing progressive gender norms in countries of origin, such as more equalitarian relations between men and women. In spite of the research scarcity, migration scholarship in the past years was able to uncover different and distinct forms of social remittances. In the following sections the paper presents main types of social remittances: ideas and aspirations, social practices, and social norms, and some of their effects.

\subsection{Ideas and aspirations}

Students of migration widely show that migration changes people's aspirations, values and ideas. As migration is often associated to access to wealth, it becomes a sought-after strategy, changing culture of origin communities in such a way that migration becomes a desirable social conduct as a means to vertical mobility (Portes, 2010). Research on culture of migration (Massey et $a l .$, 1993) widely shows that migrants and members of migrants' households acquire a higher social status; migrants tend to display their success by employing ostentatious consumption and bringing back artefacts, constructing new houses and acquiring new cars. Very often migrants and their families try to copy consumption patterns that migrants experienced abroad. Such changing patterns of consumption have also an added cultural and symbolic value. In Bangladesh, the meaning of bidesh (or abroad) ... "has been linked to material plenty and economic wealth" (Higuchi and Nanako, 2011: 28). Bangladeshi migrants returning from Japan and their families back home enjoyed an upper-middle class level by using their remittances. In such contexts, by investing in real estate and new businesses, returnees were among the richest in their communities. By such investments migrants also bring back to their communities the ideas of comfort and lifestyles that they encountered abroad. Migrants' newly built houses not only try to enhance migrant households' standard of living; in many cases, they resemble houses from destination countries, such as with Alpine houses in the Albanian villages in Macedonia, and "Italian" houses in Romanian ones (Cingolani, 2009; Markov, 2013). Migrants' clothes and consumption tend to emulate Western 
lifestyles, their aspirations being influenced by their experiences abroad. These imported models of lifestyle and wealth tend to enhance investments in human capital through education and more health-conscious attitudes (Levitt and Lamba-Nieves, 2010).

Migration can also bring about notions of youth's growing adult and emancipating. In West Africa, 'the movement [abroad] is linked to the ability to mature' (Koenig, 2005) of the young men, and the same goes for young Romanians who had to migrate in order to be able to marry and establish new families (Horváth, 2008). With migration young people attempt to emancipate from families and social constraints, while members of deprived minorities of lower classes or social status groups hope to overcome the disadvantaged social position in which they live (Grill, 2012).

Finally, migration can involve the transfer of new political ideas (sometimes coined as political remittances) and change peoples' ideas of democracy and rule of law (Levitt and LambaNieves, 2010), related to the political culture in destination countries. The Turkish migration to Western Europe has some effects on women's political empowerment in Turkey (Akkoyunlu, 2013). Migration to Russia and the CIS countries did not have that effect, while migration towards the Arab countries are more likely to effect in the support for religious parties and religious ideologies (idem). Besides, even when migrants move to liberal democracies, they can promote conservative ideas. In some cases, the rising popularity of Hinduism in India and Islam in Pakistan may be also attributed in part to migrants adopting more conservative views (Levitt and LambaNieves, 2010).

\subsection{Practices}

One of the key areas in which social remittances are paramount is technology transfer, where migrants come with new business practices and ideas of management, skills, knowledge, social capital, and access to Western markets. Returnees are potential sources of innovation and institutional transformations (Faist, 2010), especially in the cases of highly skilled or IT workers, able to "import" new competencies into countries of origin. In such cases, social remittances may be even more important than financial remittances, and can have longer-lasting effects (Conway et al., 2012). These practices are enhanced by the establishment of knowledge and social networks across borders (Kale and Little, 2007), having a key role in developing industries in India, China, Israel, and Ireland. Indian migrants for instance provided knowledge and market access to the developing Indian software industry and pharmaceutical companies. Nineteen of the 20 leading Indian IT companies are founded or managed by returnees (Wescott, 2006) and in 2006 the industry offered about 700,000 jobs. Technological transfer was further facilitated by human mobility across firms in India. "Human mobility can play an important role in the knowledge-building processes of 
firms, especially where knowledge tends to be 'sticky' and remains localized within firms, regions and countries" (Kale and Little, 2007: 104). Taking stock of the emigrant population abroad, especially of scientists and brain-drain, countries such as China, South Korea and Taiwan tailored policies for return and development. As Conway et al. (2012) mention, in order to capitalize on the social remittances brought by the highly skilled, home countries should offer expanding market opportunities and viable institutional structures.

Besides technological transfers and access to foreign markets, migrants bring home new initiatives and business ideas. Albanians and Romanian returnees in Eastern Europe (Cingolani, 2009; Anghel, 2013; Markov 2013), Bangladeshi and Filipino migrants in Asia (Higuchi and Nanako, 2011; Montefrio et al., 2014) show the propensity to get involved in new lines of business back home. Thus, Bangladeshi who migrated to Japan could capitalize on their managerial skills acquired in Japan. They were able to invest their remittances and open new types of businesses. Even when financial remittances were not large, they were able to support existing companies, by better organizing the labour management upon a Japanese organizational model (Higuchi and Nanako, 2011). In Eastern Europe, Romanian returnees imported their skills in gastronomy acquired in Italy by working in, and opening new pizzerias (Cingolani, 2009; Anghel, 2013). Returnees in Palawan, Philippines, influence how non-migrant community members work and are involved in governmental or company-led land-use projects, by bringing with them expectation of prosperity and technical knowledge acquired while working in the booming oil palm industry in Malaysia (Montefrio et al., 2014). These social remittances influenced land use in Palawan and oil palm production started to displace traditional subsistence agriculture, resulting in situations when people became entirely dependent on plantation work. Thus, while some migrants opposed the extension of oil palm industry arguing that it generates environmental degradation, most of them sustained it, seeing oil palm plantation as an avenue to wealth. Finally, oil palm companies actively recruited returnees due to their technical knowledge in the oil palm industry. In other cases, such as Guatemala, migrant remittances contributed to the transformation of rainforests into cattle pastures (Montefrio et al., 2014), to the recovery of secondary vegetation, or decrease of exploitation of land and natural resources (idem). However, in all such studies, there is still scarce research to document the possible adoption of sustainable and environmentally friendly living standards under the impact of social remittances.

Migrant social remittances also channel into new social practices in countries of origin. Highly skilled returnees in Trinidad and Tobago were being involved in NGO and professional activities back home due to altruism and fulfilment of personal vocation: personal gains and achievement (Conway et al., 2012). In some other contexts, migrants' involvement was due to 
feelings of moral obligation that they felt towards their schools and the education they received in the countries of origin (Gerharz, 2014). Home town associations (HTAs) in Mexico and Dominican Republic (Itzigsohn, 2008; Alarcón, 2002) run development activities and projects in communities of origin with the purpose to develop economically and socially their origin communities. The same is with refugees and migrants involved into reconstruction and development efforts in post-conflict contexts (Al-Ali et al., 2001; Gerharz, 2014). In the case of Eritreans in Europe, they were asked to contribute with two per cent of their monthly income and additional one-off payments. These amounts were not compulsory, but considered a duty by migrants themselves. These collective remittances were directed not only to the costs of the conflict in Eritrea, but also to relief actions. In such contexts collective remittances channelled through migrants' associations, charity and Church organizations, played an important part (Al-Ali et al., 2001) and they operate well beyond the level of individuals and families, reaching entire communities, even regions.

\subsection{Social Norms}

In the past years an important question in the debate on social remittances was concerned with whether migration enhanced the diffusion of new and more equalitarian gender norms. The increasing share of women in international migration flows and the growing role of women in generating resources for their households fuelled hopes that women would be better remitter than men, or/and unequal or patriarchal relations may change into more equalitarian ones. In cases of male dominated migration, a common assumption was that migration has expanded women's power in households and communities, where women would gain more autonomy and responsibility (De Haas and van Rooij, 2010). The research however, showed a rather mixed picture. If in certain cases gender relations may change, in others, migration and remittances can actually perpetuate unequal or patriarchal gender and social relations. Dannecker (2009) for instance shows that there is a potential for women's empowerment through migration, and that Bangladeshi migrant men and women have their own visions of development that they negotiate. Vullnetari and King (2011) and Vlase (2013) also show that through migration, Albanian and Romanian women emancipate from unequal relations existing in their origin societies. However, such processes of emancipation do not translate into changes in gender norms in origin societies, as upon return, migrant women had to comply with the same patriarchal relations from societies of origin (Vlase, 2013). In Albania, women are not only essential remitters for their families, but their remittances are sometimes pejoratively called 'coffee money' (King et al., 2011). Thus, Rahman (2012) considers that patriarchy is an essential element in understanding the relationship between gender and remittances. In some patriarchal societies it is important if wives or husbands' relatives are the receivers and 
managers of remittances, as there is a bargain over the roles and limits of women's activities (De Haas and van Rooij, 2010). Even in cases when women are the spenders, they may feel the burden of the social responsibility associated with the management of households' finances. The forms of patriarchy and the destination country also matter. As opposed to migration from Egypt to the Gulf countries, migration from North African countries to Europe resulted in changing patriarchal and new, more equalitarian family norms (idem).

Besides, women migration can enhance other types of social remittances and softer social changes. Sussomboon shows how the money remitted by Thai women and their Dutch husbands is spent on consumption and meeting basic needs, but also on human development, such as investment in education and health (Sussomboon, 2008). Remittances have been shown to provide self-esteem and great appreciation for migrant women carrying the responsibility of the wellbeing of the entire family. The great expectation that parents have on daughters to marry foreign men and thus take care of the family can lead parents to hope for girls than boys. Such social responsibility have sometimes repercussions on the family relations between Thai women and their Dutch husbands, however women prefer to continue sending and spending remittances with their families in Thailand. In such cases they prefer to let the others at home think they are doing well.

Changes in gender or generational relations may be also related rather to broader changes in societies of origin, migration being one factor influencing such changes. In Guatemala, gender and ethnic hierarchies gradually changed due to the impact of migration (De Haas and van Rooij, 2010). In other cases in the Southeastern Europe, King et al. (King et al., 2011) stress that changes of patriarchal relations can mainly occur generationally. In Morocco, some significant changes, such as increasing education, changing patterns of marriage, changing fertility rates, actually come from general changes in society and are not a direct by-product of migration (De Haas and van Rooij, 2010). In Romania women saw the investment in children's education an important way for their emancipation from patriarchal norms (Vlase, 2013). The same occurs in Morocco, as "schooling is perceived as increasing the capabilities of women to take control over their own lives" (De Haas and van Rooij, 2010: 56).

Thus, the consequences of social remittances show a rather mixed outcome. Whereas in some cases they enhance individualistic attitudes and more equalitarian social norms, often prompting communities and individuals into development avenues, in some other cases it goes into the different direction. Thus, social remittances can be both positive and negative. This relates to the composition of migration flows, the segments in the destination societies that migrants are involved in, migration destination, and the capacity of migrants and returnees to effect social change and diffuse new ideas. 


\section{Conclusions and discussion}

As migration develops around the world, the flow of remittances is likely to grow. For many poor countries, remittances represent and will continue to represent the main source of capital. Hopes are revolving around the potential of remittances for development and change in poor countries, however results are often mixed. Results from a number studies show that remittances represent a large part of the GDP in many countries, for instance in most of the Eastern European countries remittances constitute a significant portion of the GDP. At the level of household and communities of origin, remittances tend to reduce poverty. However, the role of remittances on inequality is often mixed. If some studies show that remittances have negative effects on inequality, a few others emphasize the opposite. Concerning the use of remittances, studies found that remittances are used for improvement in human capital, as opposed to the view that remittances are mostly spent on consumption. In different post-socialist countries, such investment was, however, inconclusive. Whereas in Albania there was no clear influence of remittances on education, in Tajikistan remittances and presence of migrants in families tended to lead to the growth of girls' school enrolment.

Studies on financial remittances showed mixed results concerning the positive and negative effects of remittances. Yet studies of social remittances are even vaguer in assessing such effects, at least for the fact that social remittances are harder to define and measure. From the existing literature we reviewed the types of social remittances: ideas, practices and norms. The paper analysed the role of ideas - how migration created new understandings, consumption and wealth; of practices - how new practices of business were transferred by migrants into communities and countries of origin; and of social norms - how gender norms were brought about by migration. In bringing together studies on both financial and social remittances, the paper thus maps the rich, timely, and ongoing discussion in the studies of migration, remittances and development.

The different effects of remittances on relevant outcomes, such as education, for the growth and development of poor countries lead to conclude that the role that international transfers can play is strictly dependent on the context of analysis. It explains why some studies conclude for positive effects of remittances and others support the opposite. The debate on whether or not remittances are used in a productive way should first consider the "constraints" - political instability, corruption, lack of infrastructure, lack of business regulations, lack of infrastructure - under which remittances are received. In fact, remittances can represent a tool but not a solution for development. 


\section{References}

Acosta, P. (2007). Entrepreneurship, Labour Markets, and International Remittances: Evidence from El Salvador. In: C. Özden and M. Schiff (Eds.), International Migration, Economic Development \& Policy. World Bank and Palgrave Macmillan, 141-159.

Acosta, P., Calderon, C., Fajnzylber, P., Lopez, H. (2008). What is the Impact of International Remittances on Poverty and Inequality in Latin America? World Development, 36 (1), 89-114.

Adams, R. Jr. (2011). Evaluating the Economic Impact of International Remittances On Developing Countries Using Household Surveys: A Literature Review. Journal of Development Studies 47(6), 809-828.

Adams, R. Jr., Page, J. (2005). Do International Migration and Remittances Reduce Poverty in Developing Countries? World Development 33 (10), 1645-1669.

Adams, R. Jr., Cuecuecha, A., Page, J. (2008a). Remittances, Consumption and Investment in Ghana. Policy Research Working Paper Series 4515, The World Bank.

Adams, R. Jr., Cuecuecha, A., Page, J. (2008b). The Impact of Remittances on Poverty and Inequality in Ghana. Policy Research Working Paper Series 4732, The World Bank.

Adams, R. Jr., Cuecuecha, A. (2010a). Remittances, Household Expenditure and Investment in Guatemala. World Development 38(11), 1626-1641.

Adams, R. Jr., Cuecuecha, A. (2010b). The Economic Impact of International Remittances on Poverty and Household Consumption and Investment in Indonesia. Policy Research Working Paper Series 5433, The World Bank.

Akkoyunlu, Ş. (2013). How migrants' social remittances have empowered women in Turkey? Commentaries, EU Neighbourhood. M. P. Centre. Florence, EUI. 2014.

Al-Ali, N., Black, R., Khalid, K. (2001). Refugees and Transnationalism: The Experience of Bosnian and Eritreans in Europe. Journal of Ethnic and Migration Studies 27(4), 615-634.

Alarcón, R. (2002). The Development of Home Town Associations in the United States and the use of Social Remittances in Mexico. Sending Money Home: Hispanic Remittances and Community Development. R. de la Garza and B. L. Lowell, Rowman \& Littlefield Publishers.

Amuedo-Dorantes, C., Pozo S. (2004). Workers' Remittances and the Real Exchange Rate: A Paradox of Gifts. World Development 32 (8), 1407-1417.

Amuedo-Dorantes, C., Pozo S. (2006). Remittances as Insurances: Evidence from Mexican Immigrants. Journal of Population Economics 19, 227-254.

Ang, P. A., Sugiyarto, G., \& Jha, S. (2009). Remittances and Household Behavior in the Philippines, ADB Economics Working Paper Series 188, Asian Development Bank.

Anghel, R. G. (2013). Romanians in Western Europe. Migration, Status Dilemmas and Transnational Connections, Lexington Books: Rowman and Littlefield. 
Barham,B., Boucher, S. (1998). Migration, Remittances and Inequality: Estimating the Net Effects of Migration on Income Distribution. Journal of Development Economics, 55 (3), 307-331.

Boccagni, P. and F. Decimo (2013). Mapping Social Remittances. Migration Letters 10(1): 1-10.

Castaldo, A., Reilly, B. (2007). Do Migrant Remittances Affect the Consumption Patterns of Albanian Households? South-Eastern Europe Journal of Economics 5 (1), 25-54.

Catrinescu, N., León-Ledesma, M., Piracha, M., Quillin, B. (2009). Remittances, Institutions and Economic Growth. World Development 37 (1), 81-92.

Cattaneo, C. (2012). Migrants' International transfers and Educational Expenditure. Economics of Transition 20 (1), 163-193.

Chami, R., Fullenkamp, C., Jahjah, S. (2005). Are Immigrant Remittance Flows a Source of Capital for Development? IMF Staff Papers 52 (1), 55-81.

Cingolani, P. (2009). Romeni d'Italia. Migrazioni, Vita Quotidiana e Legami Transnazionali. Bologna, Il Mulino.

Clément, M. (2011). Remittances and Expenditure Patterns in Tajikistan: A Propensity Score Matching Analysis. Asian Development Review 28 (2). 58-87.

Conway, D., Potter, R., St.Bernard, G. (2012). Diaspora Return of Transnational Migrants to Trinidad and Tobago: The Additional Contributions of Social Remittances. International Development Planning Reivew 34(2), 189-209.

Dannecker, P. (2009). Migrant Visions of Development: A Gendered Approach. Population, Space and Place 15(2), 119 - 132.

De, P., Ratha, D. (2005). Remittance Income and Household Welfare: Evidence from Sri Lanka Integrated Household Survey. Unpublished Paper. Development Research Group, World Bank, Washington, DC.

De Haas, H. and A. van Rooij (2010). Migration as Emancipation? The Impact of Internal and International Migration on the Position of Women Left Behind in Rural Morocco. Oxford Development Studies 38(1): 43-62.

Démurger, S., Xu, H. (2011). Return Migrants: The Rise of New Entrepreneurs in Rural China. World Development 39 (10), 351-372.

Dustmann, C., Kirchkamp, O. (2002). The Optimal Migration Duration and Activity Choice after Re-Migration. Journal of Development Economics 67, 351-372.

Faist, T. (2010). Towards Transnational Studies: World Theories, Transnationalisatin and Changing Institutions. Journal of Ethnic and Migration Studies 36(10),1665 - 1687.

Funkhouser, E. (2006). The Effect of Emigration on the Labour Market Outcomes of the Sender Household: A Longitudinal Approach Using Data from Nicaragua. Well-Being and Social Policy 2 (2), 5-25. 
Gedeshi, I., Jorgoni, E. (2012). Social Impact of Emigration and Rural-Urban Migration in Central and Eastern Europe. Final Country Report, Albania. https://www.google.it/url?sa=t\&rct=j\&q=\&esrc=s\&source=web\&cd=1\&ved=0CDAQFjAA\&url=ht tp\%3A\%2F\%2Fec.europa.eu\%2Fsocial\%2FBlobServlet\%3FdocId\%3D8818\%26langId\%3Den\&ei $=$ tuVsU4ahDcLDygOrn4DoBA\&usg=AFQjCNEXQ7ZimUeAOYBg8Ih19UuoYfAd9g

Gerharz, E. (2014). The Politics of Reconstruction and Development in Sri Lanka. Transnational Commitments to Social Change, Routledge.

Giuliano, P., Ruiz-Arranz, M. (2009). Remittances, Financial Development and Growth. Journal of Development Economics, 90 (1), 144-152.

Ilahi, N. (2002). Return Migration and Occupational Change. Review of Development Economics 3 (2), 170-186.

Goldring, L. (2003). Re-thinking Remittances: Social and Political Dimensions of Individual and Collective Remittances. Cerlac Working Paper Series.

Goschin, Z., Roman, M, Popa, A. (2011). Determinants of Romanian International Migrants' Remittances. ERSA Conference papersersa11p1001, European Science Association.

Grill, J. (2012). 'Going Up to England': Exploring Mobilities among Roma from Eastern Slovakia. Journal of Ethnic and Migration Studies 38(8), 1269-1287.

Higuchi, N. and I. Nanako (2011). Migrant Workers Enchanted with Consumer Society: Transnationalism and Global Consumer Culture in Bangladesh. Inter-Asia Cultural Studies 13(1), 22-35.

International Organization for Migration (2013). World Migration Report 2013. Migrant WellBeing and Development. IOM, Geneva.

Horváth, I. (2008) The Culture of Migration of Rural Romanian Youth. Journal of Ethnic and Migration Studies 34(5), 771-786.

Horváth, I. Anghel, R.G. (2009). Migration and Its Consequences for Romania. Südosteuropa 57(4), 386-403.

Itzigsohn, J. (2008). Migrant Political Transnationalism and the Practice of Democracy: Dominican External Voting Rights and Salvadoran Home Town Associations. Ethnic and Racial Studies 31(4), 664-686.

Justino, P., Shemyakina, O.N. (2012). Remittances and Labour Supply in Post-Conflict Tajikistan. IZA Journal of Labour and Development 1:8.

Kale, D. and S. E. Little (2007). Flows and Cohesion: Balancing Capabilities Across an Expanded Union. Mobilities 2(1): 99-108.

Kifle, T. (2007). Do Remittances Encourage Investment in Education? Evidence from Eritrea. GEFAME Journal of African Studies, 4(1). 
Kim, N. (2007). The Impact of Remittances on Labour Supply: The Case of Jamaica. World Bank Policy Research Working Paper 4120, Washington, DC.

King, R., Castaldo, A., Vullnetari, J. (2011). Gendered Relations and Filial Duties along the GreekAlbanian Remittance Corridor. Economic Geography 87(4), 393-419.

Koenig, D. (2005). Multilocality and Social Stratification in Kita, Mali. Migration and Economy. Local and Global Dynamics. L. Trager, AltaMira, 77-102.

Kroeger, A. (2010). Do Remittances and Migration promote Children's Schooling in Tajikistan? Preliminary Version, DIW Berlin, Berlin.

León-Ledesma, M., Piracha, M. (2004). International Migration and the Role of Remittances in Eastern Europe. International Migration 42 (4), 65-83.

Levitt, P. (1998). Social Remittances: Migration Driven Local-Level Forms of Cultural Diffusion. International Migration Review 32(4): 926-948.

Levitt, P. Lamba - Nieves, D. (2010) "It's Not Just About the Economy, Stupid!": Social Remittances Revisited. Migration Policy Institute. http://www.immigrationresearchinfo.org/report/migration-policy-institute/its-not-just-about-economy-stupid-social-remittancesrevisited

Lindley, A. (2009). The Early-Morning Phonecall: Remittances from a Refugee Diaspora Perspective. Journal of Ethnic and Migration Studies 35(8), 1315-1334.

Lokshin, M., Bontch-Osmolovski, M., Glinskaya, E. (2010). Work-related Migration and Poverty Reduction in Nepal. Review of Development Economics, 14 (2), 323-332.

Lopez, H., Molina, L., Bussolo, M. (2007). Remittances and the Real Exchange Rate. World Bank Policy Research Working Paper 4213, World Bank, Washington, DC.

Lucas, R. E. B. (2005). International Migration and Economic Development: Lessons from LowIncome Countries. Stockholm: Expert Group on Development Issues (EGDI), Swedish Ministry for Foreign Affairs.

http://www.egdi.gov.se/pdf/International_Migration_and_Economic_Development.pdf.

Mansour, W., Chaaban, J., Litchfield, J. (2011). The Impact of Migrant Remittances on School Attendance and Education Attainment: Evidence from Jordan.

Markov, I. (2013). Migration, Remittances ans Socio-Cultural Dynamics: The Case of Albanians from the Republic of Macedonia. Southeast European and Black Sea Studies 13(2), 245-264.

Massey, D. S., Arango, J., Hugo, G., Kouaouci, A., Pellegrino, A., Taylor, E.J. (1993). Theories of International Migration: A Review and Appraisal. Population and Development Review 19(3), 431466.

Mata-Codesal, D. (2013), Linking Social and Financial Remittances in the Realms of Financial Know-How and Education in rural Ecuador. Migration Letters, 10(1), 23-32. 
McKenzie, D., Rapoport, H. (2007). Network Effects and the Dynamics of Migration and Inequality: Theory and Evidence from Mexico. Journal of Development Economics, 84 (1), 1-24.

Mesnard, A. (2004). Temporary migration and capital market imperfection. Oxford Economic Papers 56, 242-262.

Montefrio, M. J., Ortiga, Y.Y., Josol, Ma.R.C.B. (2014). Inducing Development: Social Remittances and the Expansion of Oil Palm. International Migration Review 48(1), 216-242.

Paulson, A. and Townsend, R. (2004). Entrepreneurship and Financial Constraints in Thailand. Journal of Corporate Finance 10 (2), 229-262.

Piracha, M., Vadean, F. (2010). Return Migration and Occupational Choice: Evidence from Albania. World Development 38 (8), 1141-1155.

Portes, A. (1998). Social Capital: Its Origins and Applications in Modern Sociology. Annual Review of Sociology 24, 1-24.

Portes, A. (2010). Migration and Social Change: Some Conceptual Reflections. Journal of Ethnic and Migration Studies 36(10), 1537 - 1563.

Rahman, M. M. (2012). Towards a Sociology of Migrant Remittances in Asia: Conceptual and Methodological Challenges. Journal of Ethnic and Migration Studies 38(4): 689-706.

Rajan, R., Subramanian, A. (2005). What Undermines Aid's Impact on Growth? National Bureau of Economic Research Paper 11657, National Bureau of Economic Research, Cambridge, MA.

Randazzo, T., Piracha, M. (2014). Remittances and Household Expenditure Behaviour in Senegal. IZA Discussion paper No. 8106, Bonn: Institute for Study of Labour.

Ratha, D. (2003). Workers' Remittances: An Important and Stable Source of External Development Finance. In: Global Development and Finance. Striving for Stability in Development Finance. Washington: World Bank, 157-175.

Ratha, D., Mohapatra, S., Silwal1, A. (2009). Migration and Remittance Trends 2009. A betterthan-expected outcome so far, but significant risks ahead. Migration and Development Brief 11. The World Bank.

Rodriguez, E. (1998). International Migration and Income Distribution in the Philippines. Economic Development and Culture Change, 46 (2), 329-350.

Spatafora, N. (2005). Worker Remittances and Economic Development, World Economic Outlook, April, 69-94.

Sussomboon, P. (2008). Remittances and 'Social Remittances': Their Impact on Livelihoods of Thai Women in the Netherlands and Non-Migrants in Thailand. Gender, Technology and Development 12(3), 461-482.

Taylor, J. E., Mora, J. (2006). Does Migration Reshape Expenditures in Rural Households? Evidence from Mexico. Policy Research Working Paper Series 3842, The World Bank. 
Vlase, I. (2013). Women's Social Remittances and Their Implications At Household Level: A Case Study of Romanian Migration to Italy. Migration Letters 10(1), 81-90.

Vullnetari, J. King, R. (2011). Gendering Remittances in Albania: A Human and Social Development Perspective. Gender and Development 19(1): 39-51.

Wescott, C. G. (2006) Harnessing Knowledge Exchange Among Overseas Professionals of Afghanistan, People's Republic of China, and Philippines. Social Sciences Research Council, Available at SSRN: http://ssrn.com/abstract=893246 or http://dx.doi.org/10.2139/ssrn.893246 , accessed at June, $23^{\text {rd }}, 2014$.

Woodruff, C., Zenteno (2007). Migration Networks and Microenterprises in Mexico. Journal of Development Economics 82(2), 509-528.

World Bank (2006). Global Economic Prospects 2006: Economic Implications of Remittances and Migration. Washington, D.C.: International Bank for Reconstruction and Development/ The World Bank.

World Bank (2011). Migration and Remittances Factbook 2011. Washington, D.C.: International Bank for Reconstruction and Development/ The World Bank.

World Bank (2012). Migration and Remittances during the Global Financial Crisis and Beyond. The World Bank, Washington, DC.

World Bank (2013a). Migration and Development Brief 20. Migration and Remittances Unit, Development Prospects Group, http://siteresources.worldbank.org/INTPROSPECTS/Resources/334934-1110315015165/

MigrationandDevelopmentBrief20.pdf

World Bank (2013b). Migration and Development Brief 21. Migration and Remittance Flows: Recent Trends and Outlook, 2013-20161. Development Prospects Group, http://siteresources.worldbank.org /INTPROSPECTS/ Resources/ 3349341288990760745/MigrationandDevelopmentBrief21.pdf

Yang, D. (2008). International Migration, Remittances, and Household Investment: Evidence from Philippine Migrants' Exchange Rate Shocks. The Economic Journal 118, 591-630.

Yang, D. (2004). International Migration, Human Capital, and Entrepreneurship: Evidence from Philippine Migrant's Exchange Rate Shocks. Research Program on International Migration and Development DECRG. Policy Research Working Paper 3578. World Bank, Washington, DC.

Zarate-Hoyos, G.A. (2004). Consumption and Remittances in Migrant Households: Toward a Productive Use of Remittances. Contemporary Economic Policy 22 (4), 555-565. 